\title{
Pengaruh Program UEFA Champions League di Orange TV Terhadap Minat Menonton
}

\author{
Andhika1 $^{*}$, Mohammad Fahmi², Rodji Adjid ${ }^{3}$ \\ 1,2,3 Pascasarjana Ilmu Komunikasi, London School of Public Relations Jakarta
}

\section{A R T I C L E I N F O}

Article history:

Received 01 December 2019

Received in revised form

31 December 2019

Accepted 15 January 2020

Available online 26

February 2020

\section{Kata Kunci:}

Program UEFA Champions

League, Minat menonton,

Komunitas Pena (Penya)

Real Madrid de Indonesia

Regional Jakarta

Keywords:

UEFA Champions League Program, Watching Interest Pena (Penya) Community Real Madrid de Indonesia Regional Jakarta

\begin{abstract}
A B S T R A K
Tujuan penelitian ini adalah untuk menganalisa pengaruh program UEFA Champions League di Orange TV terhadap minat menonton. Studi ini mengambil sampel pada sebuah komunitas suporter tim sepakbola yang ada di Indonesia, tepatnya komunitas Pena (Penya) Real Madrid de Indonesia Regional Jakarta. Metode penelitian yang digunakan adalah penelitian kuantitatif, dimana data penelitian berupa angka yang kemudian disusun menjadi sebuah pernyataan dan kesimpulan deskriptif. Pengumpulan data dilakukan dengan kuesioner tertutup yang sebelumnya diuji dengan uji normalitas. Kuisioner diberikan kepada 60 sampel dari populasi yang dipilih. Kemudian respon dari kuesioner diolah dan diuji menggunakan Analisa Korelasi (Pearson Correlation) dengan bantuan software SPSS. Hasil penelitian ini menunjukkan bahwa Program UEFA Champions League di Orange TV secara keseluruhan berpengaruh secara signifikan sebesar $65,2 \%$ terhadap minat menonton komunitas Pena (Penya) Real Madrid de Indonesia Regional Jakarta dan sisanya sebesar $34,8 \%$ dipengaruhi oleh faktor-faktor lain yang tidak diteliti dalam penelitian ini.
\end{abstract}

\section{A B S T R A C T}

The purpose of this study was to analyze the effect of the UEFA Champions League program on Orange TV on watching interest. This study took a sample on a community of football team supporters in Indonesia, specifically the Pena (Penya) community Real Madrid de Indonesia Regional Jakarta. The research method used is quantitative research, where research data in the form of numbers which are then compiled into a descriptive statement and conclusion. Data collection was carried out with a closed questionnaire that was previously tested with a normality test. Questionnaires were given to 60 samples from the selected population. Then the responses from the questionnaire were processed and tested using Correlation Analysis (Pearson Correlation) with the help of SPSS software. The results of this study indicate that the UEFA Champions League Program on Orange TV as a whole significantly influences $65.2 \%$ of the interest in watching from the Pena (Penya) community Real Madrid de Indonesia Regional Jakarta and the remaining $34.8 \%$ is influenced by other factors which was not examined in this study.

\footnotetext{
* Corresponding author.

E-mail addresses: andhikasakkai1291@gmail.com (Andhika)
} 


\section{Pendahuluan}

Manusia pada hakekatnya telah melakukan olahraga semenjak awal peradaban dimulai. Olahraga dan masyarakat merupakan suatu yang tidak terpisahkan. Olahraga dapat digambarkan sebagai sebuah representasi dari dunia sosial yang melingkupinya. Begitupun sebaliknya, olahraga juga menyumbang terbentuknya masyarakat karena olahraga bukanlah semata-mata aktivitas fisik belaka. Olahraga mengandung nilai-nilai tertentu yang bisa menyumbangkan konstruksi nilai-nilai dan budaya dalam masyarakat. Secara fungsional olahraga memiliki peran untuk menyehatkan tubuh, sementara pada sisi sosial berperan dalam menanamkan nilai-nilai dan norma kehidupan yang patut untuk direnungkan dan diterapkan. Lebih jauh lagi olahraga bahkan dapat menunjukkan karakter dan identitas sebuah bangsa (Malobulu, 2011: vi). Sepak bola adalah wadah di mana orang dari berbagai latar-belakang etnis bertemu. Terkadang pertandingan sepak bola berakhir dengan pertengkaran antar orang yang berbeda latar belakang dan suporter. Walaupun demikian, sepak bola tetap menjadi meeting point yang mendapat perhatian oleh masyarakat (Colombijn, 2010: xix-xx).

UEFA Champions League adalah kejuaraan akbar antarklub juara di masing-masing liga sepak bola Eropa yang digelar setiap tahun pada satu ajang kompetisi yang sama, dan menjadi trofi tingkat klub yang paling prestisius di se-antero Eropa. Berjuta pasang mata di berbagai belahan dunia tiap tahun disuguhi kompetisi klub level dunia yang paling diminati publik pecinta sepakbola.

Kejuaraan ini pertama kali dimulai pada musim 1955/56 dengan menggunakan kompetisi yang bernama European Champion Club's Club. Kejuaraan ini menggunakan sistem gugur dua leg, yaitu setiap tim bermain dua pertandingan (tandang-kandang). Kemudian pada musim 1992/93, titel kompetisi berubah menjadi UEFA Champions League. Total jumlah 32 klub yang berkompetisi, terbagi dalam 8 grup yang masing-masing grup terdiri dari 4 klub. Format bertanding pun diganti menjadi tiga babak kualifikasi pada awal kompetisi, satu babak kompetisi grup yang terdiri dari 32 klub dan terbagi menjadi 8 grup (format dalam bentuk tandang-kandang), dan kemudian empat babak putaran final (ketika tersisa 16 klub) dengan sistem gugur (juga tandang-kandang). Semua pertandingan dilaksanakan dalam dua leg (tandang-kandang), kecuali pada pertandingan final yang merupakan pertandingan tunggal, diselenggarakan pada sebuah tempat yang telah ditentukan oleh pihak UEFA sebelum kompetisi dimulai.

Indonesia dikenal sebagai surganya penikmat bola, mulai dari anak-anak balita sampai orang tua renta, suka menonton pertandingan sepakbola. Banyak dari mereka menonton dari TV maupun datang langsung ke lapangan sepakbola. Segala jenis pertandingan sepak bola, selalu ramai penontonnya, tak terkecuali UEFA Champions League yang ada di benua Eropa. Dengan berulangnya kompetisi ini setiap tahun dan juga selalu ditayangkan di saluran TV tertentu yang sudah mengikat kontrak dengan UEFA (tahun ini di Orange TV), peneliti ingin mengetahui seberapa besar pengaruh program UEFA Champions League terhadap minat menontonnya.

Juara terbanyak UEFA Champions League sampai saat ini adalh club asal Spanyol, Real Madrid FC. Berdasarkan hal ini, penulis tertarik untuk mengetahui tentang seberapa besarkah pengaruh program UEFA Champions League di Orange TV terhadap minat menonton para suporter komunitas Pena (Penya) Real Madrid de Indonesia Regional Jakarta yang terkenal cukup fanatik mendukung Real Madrid FC.

Tabel 1. Operasional Konsep Variabel X

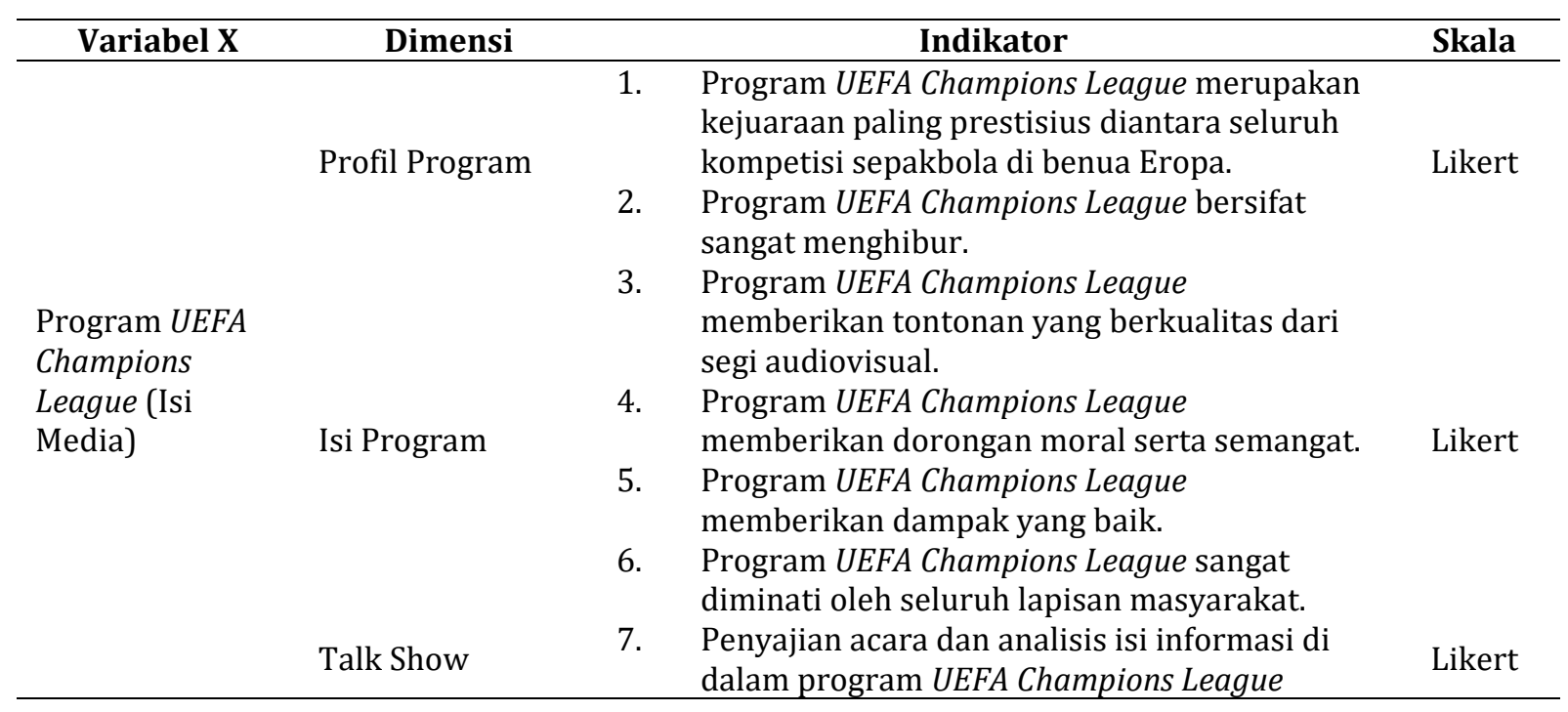




\begin{tabular}{|c|c|c|c|c|}
\hline Variabel X & Dimensi & & Indikator & Skala \\
\hline \multirow{16}{*}{$\begin{array}{l}\text { Program UEFA } \\
\text { Champions } \\
\text { League } \\
\text { (Penggunaan } \\
\text { Media) }\end{array}$} & \multirow{11}{*}{$\begin{array}{l}\text { Frekuensi, } \\
\text { Durasi, dan } \\
\text { Intensitas }\end{array}$} & & sudah baik. & \multirow{11}{*}{ Likert } \\
\hline & & 8. & Bentuk penyajian acara UEFA Champions & \\
\hline & & & League sudah bersifat modern. & \\
\hline & & 9. & $\begin{array}{l}\text { Program UEFA Champions League } \\
\text { memberikan kesan seru di dalam } \\
\text { penayangannya. }\end{array}$ & \\
\hline & & 10. & $\begin{array}{l}\text { Program UEFA Champions League membuat } \\
\text { penonton selalu ingin melihat acara tersebut. }\end{array}$ & \\
\hline & & 11. & $\begin{array}{l}\text { Sistem pengaturan tayangan program } U E F A \\
\text { Champions League sudah sangat rapi dan } \\
\text { terstruktur. }\end{array}$ & \\
\hline & & \multirow[t]{3}{*}{12.} & Dengan durasi selama pertandingan $U E F A$ & \\
\hline & & & Champions League berlangsung tidak lantas & \\
\hline & & & membuat penonton merasa bosan. & \\
\hline & & \multirow[t]{2}{*}{13.} & Program UEFA Champions League sudah & \\
\hline & & & $\begin{array}{l}\text { mencakup seluruh konten program dengan } \\
\text { sangat baik. }\end{array}$ & \\
\hline & & 14. & $\begin{array}{l}\text { Aktivitas Program UEFA Champions League } \\
\text { selalu diikuti oleh komunitas Pena (Penya) }\end{array}$ & \multirow{5}{*}{ Likert } \\
\hline & & & Real Madrid de Indonesia (PRMI). & \\
\hline & Hubungan Media & 15. & Perkembangan Program UEFA Champions & \\
\hline & & & League selalu diinformasikan oleh komunitas & \\
\hline & & & $\begin{array}{l}\text { Pena (Penya) Real Madrid de Indonesia pada } \\
\text { seluruh akun yang ada. }\end{array}$ & \\
\hline
\end{tabular}

Tabel 2. Operasional Konsep Variabel Y

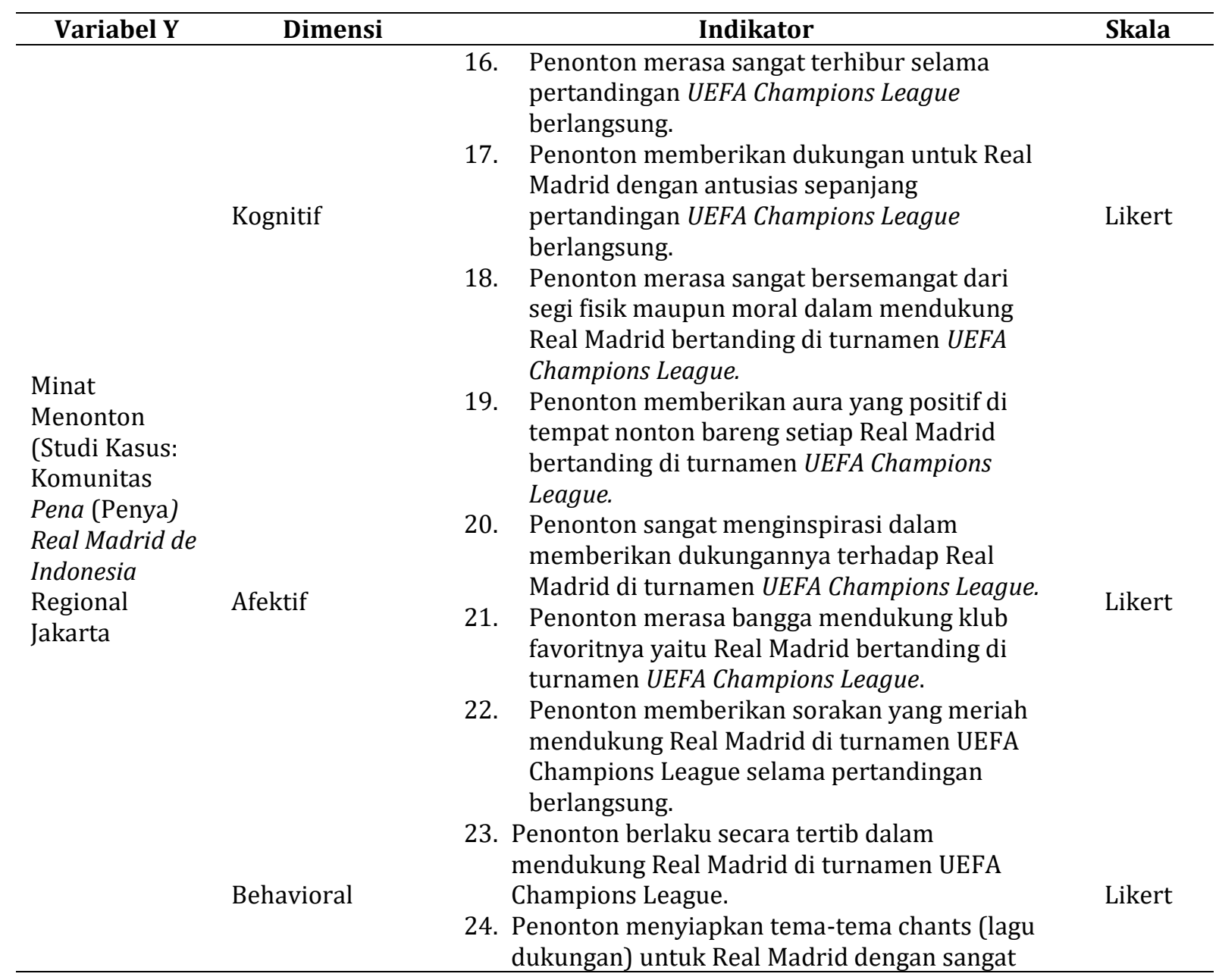




\begin{tabular}{|c|c|c|c|}
\hline Variabel Y & Dimensi & Indikator & Skala \\
\hline & & $\begin{array}{l}\text { baik untuk dibawakan ke dalam acara nonton } \\
\text { bareng UEFA Champions League. } \\
\text { 25. Penonton memperlihatkan wajah yang biasa } \\
\text { saja pada saat menonton klub kesayangannya } \\
\text { Real Madrid bertanding di turnamen UEFA } \\
\text { Champions League. } \\
\text { 26. Penonton menjadikan suasana nonton bareng } \\
\text { mendukung Real Madrid di turnamen UEFA } \\
\text { Champions League semakin nyaman dan } \\
\text { menyenangkan. } \\
\text { 27. Penonton bersikap dingin di dalam melihat } \\
\text { klub kesayangannya Real Madrid bertanding di } \\
\text { turnamen UEFA Champions League. } \\
\text { 28. Penonton melakukan tindakan provokator } \\
\text { sehingga menimbulkan kericuhan di dalam } \\
\text { acara nonton bareng UEFA Champions League. } \\
\text { 29. Penonton hanya sekedar untuk datang } \\
\text { menonton Real Madrid bertanding di turnamen } \\
\text { UEFA Champions League agar merasa terhibur. } \\
\text { 30. Penonton memberikan dukungan dari seluruh } \\
\text { jiwa maupun raganya ketika Real Madrid } \\
\text { bertanding di turnamen UEFA Champions } \\
\text { League. }\end{array}$ & \\
\hline
\end{tabular}

\section{Metode}

Penelitian ini menggunakan penelitian kuantitatif, Menurut Sugiyono (2005), penelitian kuantitatif bertujuan untuk membangun fakta, menguji teori, memberikan deskripsi statistik, mengetahui hubungan antar variabel, dan memperkirakan hasilnya.

Metode penelitian yang digunakan adalh metode survei, yaitu metode riset dengan menggunakan kuesioner sebagai instrument pengumpulan data. Tujuannya untuk memperoleh informasi tentang sejumlah responden yang dianggap mewakili populasi tertentu, kemudian diharapkan dari tujuan penelitian kuantitatif ini adalah untuk melakukan tes terhadap teori yang sudah ada sebelumnya dan melakukan pembuktian terhadap kebenaran dari teori tersebut.

Populasi dalam penelitian ini adalah Komunitas suporter club Real madrid FC yang bernama Pena (Penya) Real Madrid de Indonesia. Dari populasi ini, peneliti menetapkan 'Komunitas Pena (Penya) Real Madrid de Indonesia Regional Jakarta' sebagai sampel penelitian ini.

Kuesioner yang digunakan oleh peneliti yaitu dengan skala likert. Skala likert digunakan untuk mengukur sikap, pendapat, dan persepsi sesorang atau sekelompok orang mengenai fenomena sosial (Sugiono, 2012), umumnya dalam penelitian, fenomena sosial sudah ditetapkan oleh peneliti secara spesifik, yang selanjutnya disebut sebagai variabel penelitian. Dengan skala ini variabel yang akan diukur dijabarkan menjadi indikator variabel, kemudian indikator tersebut dijadikan sebagai titik tolak untuk menyusun item-item instrumen yang dapat berupa pertanyaan atau pernyataan.

Instrumen penelitiannya dapat dibuat dalam bentuk cheklist ataupun pilihan ganda. Setiap pertanyaan atau pernyataan yang ada dihubungkan dengan jawaban berupa ungkapan kata-kata yaitu: Sangat Tidak Setuju (STS), Tidak Setuju (TS), Netral (N), Setuju (S), dan Sangat Setuju (SS). Jawabanjawaban tersebut juga akan diberi penilaian atau skor dengan angka 1-5.

Penelitian ini diawali dengan Uji Normalitas. Uji normalitas bertujuan untuk mengetahui apakah populasi data berdistribusi normal atau tidak. Dalam penelitian ini, peneliti menggunakan metode Kolmogorov-Smirnov dengan bantuan SPSS 17.0 for windows. Prinsip kerja metode ini adalah membandingkan frekuensi kumulatif distribusi teoretik dengan frekuensi kumulatif distribusi empiric atau observasi (Siregar, 2014).

Setelah itu, dilakukan Analisis Korelasi. Korelasi merupakan teknik analisis yang termasuk dalam salah satu pengukuran asosiasi atau hubungan (measures of association). Dalam penelitian ini, analisis korelasi yang digunakan yaitu Pearson's Correlation (Product Moment). Pengukuran asosiasi berguna untuk mengukur kekuatan (strenght) dan arah hubungan-hubungan antar dua variabel atau lebih. Teknik pengukuran ini digunakan untuk mengetahui koefisien korelasi atau derajat kekuatan kekuatan hubungan 
dan membuktikan hipotesis hubungan antara variabel/data/skala interval dengan interval lainnya. (Rachmat Kriyantono, 2010).

Tabel 1. Tingkat Nilai Korelasi

\begin{tabular}{cl}
\hline Skala Korelasi & \multicolumn{1}{c}{ Tingkat Korelasi } \\
\hline$<0,20$ & Rendah sekali; lemas sekali \\
$0,20-0,39$ & Rendah tetapi pasti \\
$0,40-0,70$ & Cukup berarti \\
$0,71-0,90$ & Tinggi; Kuat \\
$>0,90$ & Sangat tinggi; Kuat sekali \\
\hline
\end{tabular}

\section{Hasil dan Pembahasan}

Responden dari penelitian ini adalah anggota komunitas Pena (Penya) Real Madrid de Indonesia Regional Jakarta. Dimana jumlah keseluruhan komunitas terpilih dari populasi berjumlah 150 orang dan batas kesalahan yang ditolerir adalah 10\%, maka di dapat 60 responden berdasarkan teknik pengambilan sampel dari rumus Yamane. Kemudian, peneliti telah memberikan pertanyaan tambahan di awal untuk mengetahui penyebaran responden, diantaranya jenis kelamin, usia, dan domisili mereka. Hal ini dilakukan untuk mendapatkan identifikasi mengenai siapa saja responden yang terlibat di dalam pengisian kuesioner tersebut.

Total responden yang menjadi objek penelitian dimana terdiri dari 50 laki-laki dan 10 perempuan. Dimana bila diukur melalui tingkat persentase yakni, 83,3\% untuk responden laki-laki dan $16,6 \%$ untuk responden perempuan. Perhitungan ini dinyatakan valid karena telah sesuai dengan sampel yang diambil sesuai dengan perhitungan yang diambil dari total populasi.

Dari total 60 responden, terdapat 4 orang atau 6,7\% berumur dibawah 17 tahun, 37 orang atau $61,7 \%$ berumur $17-25$ tahun, dan 19 orang atau $26,6 \%$ berumur diatas 25 tahun.

Jumlah responden terbanyak terdapat di Jakarta Selatan sebanyak 36 orang atau $60 \%$ dari total keseluruhan responden, diikuti Jakarta Timur sebanyak 9 orang atau 15\%, kemudian Jakarta Barat sebanyak 7 orang atau 11,67\%, Jakarta Pusat sebanyak 6 orang atau 10\%, dan terkecil yaitu Jakarta Utara sebanyak 2 orang atau $3,33 \%$ responden.

\section{A. Uji Normalitas}

Uji Normalitas untuk Variabel Program UEFA Champions League

Tabel 2. Uji Normalitas Variabel X

\begin{tabular}{llc}
\hline & & Variabel X \\
\hline $\mathrm{N}$ & & 60 \\
Normal Parameters & Mean & 63.9500 \\
& Std. Deviation & 6.15733 \\
& Absolute & .092 \\
Most Extreme Differences & Positive & .082 \\
& Negative & .092 \\
Kolmogorov-Smirnov Z & & .716 \\
Asymp. Sig. (2-tailed) & & .685 \\
\hline
\end{tabular}

Berdasarkan Tabel 2 diatas, terlihat nilai Sig 0,685. Apabila Sig $>0,05$ dinyatakan bahwa data dan instrument (kuisioner) terdistribusi normal. Dengan ini, maka variabel X dinyatakan berdistribusi normal dan valid. 


\section{B. Uji Normalitas untuk Variabel Minat Menonton}

Tabel 3. Uji Normalitas Variabel Y

\begin{tabular}{llc}
\hline & & Variabel Y \\
\hline $\mathrm{N}$ & & 60 \\
Normal Parameters ${ }^{\mathrm{a}, \mathrm{b}}$ & Mean & 62.3000 \\
& Std. Deviation & 7.95176 \\
Most Extreme Differences & Absolute & .082 \\
& Positive & .082 \\
Kolmogorov-Smirnov Z & Negative & -.077 \\
Asymp. Sig. (2-tailed) & & .632 \\
\hline
\end{tabular}

Berdasarkan Tabel 3 diatas terlihat nilai Sig 0,819. Apabila Sig > 0,05 dinyatakan bahwa data dan instrument (kuisoner) berdistribusi normal. Dengan ini, maka dinyatakan bahwa variabel Y berdistribusi normal dan valid.

\section{Analisis Korelasi}

Analisis hubungan (korelasi) pada penelitian ini bertujuan untuk melihat signifikansi dari hubungan kausal antara variabel bebas dan terikat. Variabel X pada penelitian ini adalah program UEFA Champions League yang memberikan pengaruh terhadap variabel Y, yaitu minat menonton. Berikut hasil uji korelasi dalam bentuk tabel untuk mengetahui hubungan antara dua variabel ini.

Tabel 4. Analisis Korelasi

\begin{tabular}{llcc}
\hline & & Variabel X & Variabel Y \\
\hline \multirow{2}{*}{ Variabel X } & Pearson Correlation & 1 & $.652^{* *}$ \\
& Sig. (2-tailed) & & .000 \\
Variabel Y & $\mathrm{N}$ & 60 & 60 \\
& Pearson Correlation & $.652^{* *}$ & 1 \\
& Sig. (2-tailed) & .000 & 60 \\
\hline
\end{tabular}

Berdasarkan Tabel 4 diatas, dapat dinyatakan bahwa tingkat hubungan variabel program UEFA Champions League dengan variabel minat menonton sebesar 0,652 dan bersifat searah, kuat, dan signifikan.

\section{Simpulan dan Saran}

Kesimpulan dari penelitian ini menunjukkan bahwa ada pengaruh yang signifikan antara program UEFA Champions League di Orange TV terhadap minat menonton pada komunitas Pena (Penya) Real Madrid de Indonesia regional Jakarta. Hal ini berdasarkan analisis korelasi yang menyatakan bahwa tingkat hubungan variabel program UEFA Champions League dengan variabel minat menonton sebesar 0,652 . Nilai ini menunjukkan bahwa ada pengaruh antara 2 variabel yang diteliti. Pengaruh ini bersifat searah, kuat, dan signifikan.

Dengan penelitian ini, kita mengetahui bahwa keseluruhan variabel X, baik itu isi media maupun penggunaan media, semuanya dikatakan memiliki respon positif yang sangat besar sehingga perlu dipertahankan untuk kedepannya. Untuk pernyataan keseluruhan variabel $\mathrm{Y}$ dari minat menonton komunitas Pena (Penya) Real Madrid de Indonesia, semuanya memiliki respon positif yang sangat besar sehingga perlu dipertahankan untuk kedepannya.

\section{Daftar Rujukan}

Baksin, Askurifai. (2009). Jurnalistik Televisi: Teori dan Praktik. Bandung: Simbiosa Rekatama Media.

Bungin, Burhan. (2011). Sosiologi Komunikasi. Jakarta: Prenada Media Group.

Cangara, Hafied H. (2006). Pengantar Ilmu Komunikasi. Jakarta: PT Rajagrafindo Persada. 
Colombijn, Freek, "The Politics of Indonesian Footbal", dalam Archipel No. 59/2000.

Djamal, Hidajanto dan Andi Fachruddin. (2013). Dasar-Dasar Penyiaran (Sejarah, Organisasi, Operasional, dan Regulasi). Jakarta: Kencana Prenada Media Group.

Harahap, Edi dan H. Syarwani Ahmad. (2014). Komunikasi Antar Pribadi (Perilaku Insani Dalam Organisasi Pendidikan). Jakarta: Rajagrafindo Persada.

Kriyantono, Rachmat. (2010). Teknik Praktis Riset Komunikasi. Jakarta: Kencana Prenada Media Group.

Malobulu, Syarifudin dkk., Olahraga dan Pendidikan Jasmani dalam Wajah Keutuhan NKRI. Jakarta: Ardadizya Jaya, 2011.

Ma’u, Mellius dan J. Santoso. (2014). Teknik Dasar Bermain Sepak Bola. Yogyakarta: Cakrawala.

Mulyana, Deddy. (2014). Ilmu Komunikasi Suatu Pengantar. Bandung: PT Remaja Rosdakarya.

Nugroho, Untung. (2015). Langkah Sukses Menjadi Pemimpin Melalui Media Olahraga. Jawa Tengah: CV. Sarnu Untung.

Rahman, Agus Abdul. (2013). Psikologi Sosial (Integrasi Pengetahuan Wahyu dan Pengetahuan Empirik). Jakarta: Rajagrafindo Persada

Sastra, Iwel. (2016). Inspirasi Sukses Dari Sepak Bola. Jakarta: Gemilang.

Sugiyono. (2009). Metode Penelitian Kuantitatif dan Kualitatif. Bandung: CV Alfabeta.

Siregar, Syofian. (2014). Metode Penelitian Kuantitatif: Dilengkapi Perbandingan Perhitungan Manual dan SPSS. Jakarta: Prenada Media Group.

Susilana, Rudi \& Cepi Riyana. (2007). Media Pembelajaran. Bandung: CV Wacana Prim.

TW, Gheeto. (2013). GOL! Memahami Kesuksesan Dari Kacamata Sepakbola. Jakarta: PT Bhuana Ilmu Populer. 